\title{
Vulnerability Index Elaboration for Climate Change Adaptation in Peru
}

\author{
Marta Tostes Vieira ${ }^{1}$, Alfredo Villavicencio Vieira ${ }^{2}$ and Claudia Motta Villa García ${ }^{3}$
}

\begin{abstract}
This paper evidences one of the most relevant information gaps of climate change adaptation in Peru: its vulnerabilities. First, it contextualizes main national level impacts and progress made in adaptation measures definition from prioritized thematic areas. Then, it addresses the difficulty of finding tools to measure climatic risk level. For instance, this arises the need to focus on the vulnerability associated with climate change adaptation efforts. Therefore, a vulnerability index based on a multi criteria analysis is proposed, with three parts. In the first one, three-work axes were chosen following the fifth IPCC report guidelines: climatic phenomena dangers, territorial exposure, and subjects' vulnerability. The territorial area analysis was carried on at district level. With regard to subjects, five indicator groups were identified, and measurable variables were chosen: population; species and ecosystems; functions, services, and environmental municipalities' assets; economic, social and cultural assets; and infrastructure. Next, data was searched for each variable and it was systematized in a multi-criteria database. Finally, an index (0-15) was developed to calculate socioclimatic vulnerability of all the Peruvian District Municipalities. They were classified according to social, climatic, and socio-climatic vulnerability range. This facilitates a targeting instrument for public policies that can generate better climate change risk management and contributes to commitments fulfillment of the Sustainable Development Goals.
\end{abstract}

Keywords: Climate change, Vulnerability, Climate change adaptation, Socio-climatic vulnerabilities, Climate risk, Sustainable Development Goals

\section{Introduction}

Despite efforts in all countries and regions related to environmental policy, United Nations (UN) "Global Environment Outlook" reports warn about worldwide deterioration of the ecosystem overall state (Naciones Unidas, 2019). "Since life appeared, about four billion years ago, never a single species by itself has changed the global ecology... Already our impact runs parallel to that of ice ages and tectonic movements" (Harari, 2015, pág. 88). Therefore, urgent action on an unprecedented scale is essential to stop, reverse the situation and adapt to protect human and environmental health to maintain current and future integrity of global ecosystems.

Sustainable Development Goals sought reflection in national and local plans, where concern for natural resources governance is increasing. A great responsibility befalls on objective number 13, related to mitigate and adapt to climate change (Naciones Unidas, 2015). There are many differences in environmental effectiveness with the unsustainable production and consumption model idealized worldwide. Some of them are the high development gaps, the limited access to appropriate technologies, the scarce or null representation of future generations in negotiation tables, the fact that "the benefits of

| 1 Pontificia Universidad Católica del Perú (PUCP) in the Management Science Academic Department ${ }^{2}$ Senior Researcher, graduated Economist from Pontificia Universidad Católica del Perú (PUCP)

${ }^{3}$ Main researcher at group Excelencia y Desarrollo SAC, Social Manager from Management Faculty of Pontificia Universidad Católica del Perú (PUCP) 
climate change mitigation remain fundamentally global and long-term, while their costs are local and immediate" (Tirole, 2016, pág. 221). Therefore, population vulnerability monitoring requires effective mechanisms to focus efforts against environmental deterioration in Peru, one of the countries that could have the greatest impact.

At international level, progress has already been made in standardizing mitigation measures monitoring. At local level, the challenge must be assumed in terms of adapting to the effects generated from alteration of averages, variability and extremes of indicators such as temperature and rainfall (MINAM - CENEPRED, 2013). Peru does not have local disaggregated projections about these changes, although it has defined adaptation measures against risks but without considering adequate targeting in most cases.

The objective of this study is to estimate a risk index for climate change adaptation in Peru based on a multicriteria analysis. It has departmental level distribution that takes into account information at district level of subjects that must adapt to climate change: population, species and ecosystems, functions, services and environmental assets, economic, cultural and social assets, and infrastructure. These are exposed to dangers coming from climatic phenomena of different origins.

Coming next is a literature review on the state of the art of climate change adaptation, followed by a context analysis of information requirements for decision-making focalization. Likewise, the methodology proposes a multicriteria analysis, from which the main findings are presented. It allows reaching conclusions that aim to contribute for a better addressing of national adaptation strategies to climate change to promote sustainable development in Peru.

\section{Literature Review}

The problem of climate change has been discussed both internationally and nationally, due to the variety of causes that originate it. They include the anthropocentric action that has altered the world in unforeseen ways, turning the planet into a single ecological unit with several homogeneous elements (BID, CEPAL, 2014) (Valverde, 2014). The climate change influence has been differentiated according to regions that have geographical and ecological characteristic features and that have certain behavior patterns resulting from common global elements (Leal, 2015).

Faced with this increasingly worrying reality, since 1988 work has been ongoing through the Intergovernmental Panel on Climate Change (IPCC). Since then, a series of reports were produced where the state of scientific, technical and socioeconomic knowledge about the change is shared, as well as its causes, repercussions and possible responses (IPCC, 2014). Among these evidences, the origin of climate change was identified as occurring largely by human activity (Schmidt-Thomé, Ha Nguyen, Long Pham, Jarva, \& Nouttimäki, 2015). These changes have had serious consequences that increase the world's disaster risk level (GIZ, 2014). The magnitude of the challenges the world faces today is evidenced by the recent statistics on extreme events (C. Glavovic \& P. Smith, 2014), so one of the great challenges in the 21st century is to develop adaptive capacities. Adaptation to climate change effects consists of adjusting natural or human systems in response to real climatic stimuli anticipating its effects, which will enable to moderate damage and to take advantage of opportunities (IPCC, 2001). According to IPCC 5th 
Asessment Report, different options to develop and measure adaptation strategies (IPCC, 2014) have been worked. It has become one of the reference points for elaboration of different national strategies on climate change. Likewise, it is important to point out that over time adaptation key concepts have evolved. Thus, although risk reduction has always been considered as the main adaptation objective, about 10 years ago risk consisted of threat and vulnerability (Naciones Unidas, 2008), while today, as mentioned in the IPCC report, risk consists of hazards, exposure and vulnerability (IPCC, 2014).

On the other hand, about adaptation options choice will greatly depend on risks and vulnerabilities identification (GIZ, 2014). Thus, the report mentions three adaptation action categories: physical and structural, social and institutional. However, it also mentions as one of the pillars for successful adaptation implementation actions the need to have access to information, technology and financing (Christiansen, Schaer, Larsen, \& Naswa, 2016).

At this point it is important to emphasize that the information contributes not only to adaptation implementation actions but also to develop tools that facilitate risk measurement to focus the proposed actions (Gohari, Javad, \& Eslamian, 2015) (Mathew, Trück, Truong, \& Davies, 2016) (Naswa, y otros, 2015). This way, measurement forms have been developed for different purposes that range from estimating individuals and communities' vulnerability to making comparison between countries (Brooks, Nick, 2014). However, the report points out the challenge that still exists to find the appropriate measurement and the need to have a monitoring and evaluation component as part of adaptation capacities development (Bouroncle, Rodríguez, \& Florián, 2016) (Climate - eval, 2015) (Smith, Cuccillato, \& Anderson, 2014).

\section{Context}

As seen, climate change has been generating impacts on natural and human systems both in continents and oceans (IPCC, 2014), for which different nations are implementing adaptation and mitigation measures. Such is the case of Central and South America where specifically adaptation measures are applied based on ecosystems that include protected areas, conservation agreements and community management. For its part, Peru, with its natural characteristics, constitutes a very exposed territory to climate change impacts, which generates great vulnerability not only internally, but also in the ecosystems of the geopolitical environment (MINAM, 2016). The Peruvian government has assumed international commitments to deal with the adverse climatological effects for which it has developed various national and sectoral documents that will be briefly reviewed below.

In 2014, the National Climate Change Strategy (ENCC) was elaborated. It detailed the national context and presented the objectives and actions to be taken to face climate change. Likewise, it established the synergies and management tools required to make the strategy operational. This document represented the fulfillment of the Peruvian State commitment to act against climate change in an integrated, transversal and multisectoral manner (MINAM, 2014). Two years later, in 2016, the Third National Communication was prepared in which the progress made on climate change was reported since 2010, 
when the Second National Communication was presented. The third communication emphasized the advance of the ENCC formulation, the development of mitigation measures (NAMA), the establishment of "Infocarbon" and the expansion of the hydrometeorological stations network for climate observation, among others. Likewise, the communication highlighted the fulfillment of international commitments with the presentation, in 2015, of Nationally Determined Contributions (NDC), which represented a great step for the country in terms of climate change (MINAM, 2016).

In 2017, with the objective of preparing NDC's updating and formulating the National Adaptation Plan to Climate Change (NAP), the Multisectorial Working Group (MWG) was created. This constituted a strategic process, both for mitigation and adaptation, to integrate decision-making of various environment stakeholders. The MWG developed its work on adaptation based on five priority thematic areas: forests, agriculture, fisheries and aquaculture, health and water. For them it defined goals, products and a total of 91 adaptation measures with their respective indicators (151 indicators). Likewise, and in parallel, the Framework Law on Climate Change (No. 30754) was given and approved. The discussion of its Regulation was initiated, which included the $M$ \& E system for climate change adaptation.

Although in Peru M \& E systems have only been developed for programs and projects, the National Center for Strategic Planning (CEPLAN) is in the initial process of designing $\mathrm{M} \& \mathrm{E}$ systems for national public sector. Even so, within the framework of NDC, it has been necessary to make a proposal for a $\mathrm{M} \& \mathrm{E}$ system in order to have tools to follow up the proposed adaptation measures. That is why the $\mathrm{M} \& \mathrm{E}$ system objectives were established and based on competent sectors' existing information However, the reality that decision makers found was lack of complete and up-to-date databases that could allow to know the country's current situation and to make detailed climate change projections. This information gap became more relevant given the need to have tools to facilitate targeting of adaptation actions. Although adaptation measures were already available, it was not clear which regions and districts had higher vulnerability level and, therefore, higher urgency level for adaptation actions implementation. Thus, the need arises to develop tools for estimation of each district's vulnerability index and to identify to which climatic phenomena it is most exposed.

To this end, the starting point will be the subjects exposed to climate change impacts and from which the index will be built. These are population; livelihoods; species or ecosystems; environmental functions, services and resources; infrastructure; or economic, social or cultural assets (IPCC, 2014). The construction of the index that follows started with data search to identify, the vulnerability level for each district, based on the aforementioned subjects.

\section{Methodology}

The methodology of the work carried out during the investigation allows for the collection and analysis of relevant information for a better understanding of different time of vulnerabilities against adaptation to climate change. In this sense, we create proxy variables to six types of vulnerabilities.

First, the exposure to natural disasters will be translated as the summation of the binary 
variables (zero or one) of the exposure to individual climatic phenomena. The data for 2017 is provided by the National Institute of Statistics and Informatic (INEI, Local Public Services)'s fifth module of the National Regional Registry of Municipalities (RENAMU). In this sense, the fourteen (14) climatic phenomena that are presented as alternatives for the response of this question in the RENAMU are: alluvions, landslides, hill landslides, mudslides, hailstorms, frosts, snowfall, heavy rains, thunderstorms Floods, droughts, strong winds, forest fires, urban fires.

Second, as it was mentioned before, there are five types of subjects that will be address for vulnerability purposes: population; species and ecosystems; environmental functions, services, and assets; economic, social, and cultural assets; and infrastructure. That is how the population vulnerability is understood as the sum of the trend of two variables: the district's monetary poverty rate - from zero to one (by the 2013 National Household Survey, made by the INEI) -, and a socio-environmental conflict variable. Using data from the Monthly Report No. 178 (December 2018) on Social Conflicts of the Ombudsman's Office, (Defensoría del Pueblo, 2017) if the district has one or more socio-environmental conflicts, the variable will take the value of two, while if it is not due to environmental reasons, it will be equivalent to one. If there is no conflict, that variable will take the value of zero. Therefore, the population vulnerability will reach values between zero (0) and three (3) for each district of Peru with data for 2013.

On the vulnerability of species and ecosystems, it will be composed by the sum of the accumulated deforestation rate from 2001 to $2014^{1}$ and the number of Natural Protected Area (ANP) in the district. The first variable, the number of ANP within its territory, will be obtained through an individual search of each ANP in the Peruvian National Service of Natural Protected Areas. It is worth highlighting that the district that has a greater number of ANP is Echarate (La Convención province, Cusco), so the variable takes a value between zero (0) and four (4). As the accumulated deforestation rate will be a percentage, it will take the value between zero and one. In this way, the vulnerability of species and ecosystems will range in between zero (0) and five (5).

In relation to the vulnerability of environmental functions, services and assets of the municipalities, this research uses again INEIs' fifth module of the National Registry of Municipalities (RENAMU). The following investigation uses the summation of two variables as a proxy: if the Municipality has an Environmental Office or Unit and if the Municipality has Disaster Risk Management instruments. As this variable reflects a vulnerability, when having said units and instruments reduces the vulnerability, its binary variables will have opposite values to the regular ones. That is, both variables take the value of one if the Municipality does not have such department or services and zero if it does. Thus, the environmental functions, services and assets of the municipalities will be between zero (0) and two (2).

Furthermore, the vulnerability associated with economic, social and cultural assets will also be obtained from INEI's fifth module of the RENAMU. In this way, three variables build this variable. First, the agricultural area (which, being a percentage, oscillates between zero and one) will be used in the National Agricultural Census, CENAGRO 2012. Nevertheless, a proxy variable was constructed that will take the value of 1 (one) if

${ }^{1}$ Obtained by data provided by the Peruvian Ministry of Environment for a former consulting product. 
the number of hectares of agricultural land is greater than the population of the district ${ }^{2}$ and zero (0), if not. The second variable will be the binary (zero if no, one if yes) question if the Municipality carried out activities to encourage tourism in the district in 2016. Therefore, the economic, social and cultural assets will range between zero and two.

For the infrastructure variable, it will consist of the summation of three binary variables obtained in INEI's fifth module of its RENAMU: (i) if the Municipality received financing for infrastructure works and/or social programs in the district in 2016; (ii) if the Municipality has received transfers of social and productive infrastructure projects in 2016; and, (iii), if the Municipality administers health facilities that work in the district. Therefore, the infrastructure variable will have a range between zero (0) and three (3).

As a result, the total vulnerability of the five previously defined subjects will add between zero (0) and fifteen (15). Moreover, once the socio-climatic vulnerability of all the districts of Peru has been calculated, the classification by ranges of vulnerability (social, climatic and socio-climatic) and data disaggregation by average population ranges of said districts will be done.

This methodology has been constraint by data accessibility, so additional steps should be taken with the information provided. For instance, INEI's RENAMU has different modules but, according to the previously developed theoretical framework and literature review, the potential data for building each one of the proxies for vulnerabilities is certainly limited. Furthermore, the exposure to natural disasters is being measured by a proxy that excludes frequency and magnitude of the impact, as those variables are not in INEI's RENAMU.

It is important to know that the findings by vulnerability in the next part, will present potential correlations by looking to the data trends between the vulnerabilities' proxies, average district population, and average district agricultural area. Nevertheless, due to limitations on the scope of the investigation, no regression has been run, which implies that none of the correlation claims have been verified (that is why they are mentioned as "apparent").

\section{Findings}

Below is a separate analysis of each subject that has made a vulnerabilities analysis against adaptation to climate change. ${ }^{3}$

\section{Exposure to Natural Disasters}

As previously explained, exposure to natural disasters ranges from zero (0) to fourteen (14). The dispersion by department is alarming, being that the department of Apurímac is (in a district average) exposed to 7.51 climatic phenomena, Madre de Dios to 7.0, and Cusco to 6.9. On the other hand, the department of Callao has an average climate exposure of 1.83, Lambayeque of 2.02, and Lima of 2.55. While the departments with greater exposure to average climatic phenomena are found in the regions of the

\footnotetext{
2 As it is understood that those who fill this condition more vulnerable.

${ }^{3}$ For the statistics analyzed in this section, the number of will be considered as 1736 districts. Informatic data constraints reduced the dataset of municipalities in less than $8 \%$, but without creating a data bias in any of the outcomes.
} 
highlands, high forest, and low jungle, those with lower values are mostly from the coast. In a more disaggregated manner, 8 of the 9 districts with the greatest exposure to climatic phenomena are found in departments located in the Peruvian highlands. These districts have an exposure of thirteen to more diverse climatic phenomena of great impact for communities, infrastructure and natural resources, with different combinations of these phenomena. For example, while some districts are affected by hailstorms and snowfalls (for example, Watermelon in the province of Sandía, Puno department) and others were exposed with floods, thunderstorms, alluvium and heavy rains (Chincheros in Chincheros, Apurímac), others they were both (Juan Espinoza de Medrano in Antabamba, Apurímac). On the other hand, there were 112 districts that did not have any exposure to weather events during 2017. Most of these districts were found on the Peruvian coast, particularly in the departments of Lima, Ica, Lambayeque, Ancash and La Libertad, despite of having some exceptions in the mountains (Cachimayo in Anta, Cusco) and in the jungle (Capisapa in Picota, San Martín).

The majority of districts in Peru (63.94\%) are exposed to between one five climatic phenomena, while $26.84 \%$ is between six and nine. More alarmingly, $7.20 \%$ of the districts of Peru are exposed to ten or more climatic phenomena. Likewise, the natural disaster to which the districts are most exposed (illustrated by Table 2) in heavy rains (1163 districts, 66.99\%), droughts (880 districts, 50.69\%), strong winds (801 districts, $46.14 \%$ ), frost (739 districts, 42.57\%) and landslides (684 districts, 39.4\%). On the other hand, floods, snowfalls and earthquakes affect the least number of districts with 80 (4.61\%), $248(14.29 \%)$ and 303 exposed (17.45\%), respectively.

As detailed previously, the population vulnerability (where the subject is the population) is measured by two variables in particular: the incidence of monetary poverty and social conflicts (value of one) or socio-environmental (value of two). The department with the highest average population vulnerability was Madre de Dios with 2.05, while other departments whose average population vulnerability stands out for their high values are Ayacucho (1.45), Junín (1.38), Puno (1.28), Apurímac (1.18) and Loreto (1.10). It is worth remarking that most of the districts located within these departments with high population vulnerabilities are in located again in the highlands, high forest and, low jungle. On the other hand, the departments with a lower average population vulnerability were Ica (0.08), Callao (0.11), Tumbes (0.14) and Tacna (0.28), which have a majority of districts in the natural region of the coast. Likewise, the districts with the greatest population vulnerability are those that, due to the weight of the variables, have at least one socio-environmental conflict within it. Therefore, what really differentiates the ten most vulnerable districts are their poverty rates. ${ }^{4}$

\footnotetext{
${ }^{4}$ For example, the district of El Cenepa (province of Condorcanqui, department of Amazonas) has an incidence of monetary poverty of $88.12 \%$, in addition to at least one socio-environmental conflict. The same could be said of Sarhua (Victor Fajardo, Ayacucho), Huaya (Victor Fajardo, Ayacucho), Sorochuco (Celendin, Cajamarca), Cachachi (Cajabamba, Cajamarca) and Huasmín (Celendín, Cajamarca) who, in addition to having at least a socio-environmental conflict, have $87.41 \%, 86.49 \%, 85.92 \%, 83.72 \%, 83.23 \%$ of monetary poverty, respectively. On the other hands, the districts with the lower population vulnerability were San Isidro (Lima, Lima), Miraflores (Lima, Lima), San Borja (Lima, Lima), Wanchaq (Cusco, Cusco) and La Punta (Callao, Callao) which have $0.17 \%, 0.23 \%, 0.61 \%, 0.62 \%$ and $0.76 \%$ of monetary poverty, respectively, and no conflict.
} 
The first result that stands out is that $42.93 \%$ (741) of the districts have a population vulnerability lower than 0.5 , which indicates that they had no conflict of any kind and their monetary poverty rates ${ }^{5}$ are comparatively lower. In contrast, $31.81 \%$ (549) of the districts have a population vulnerability of between 0.5 and 1, demonstrating absence of conflict but high rates of monetary poverty. Similarly, $10.5 \%$ of the districts had between 1 and 1.49 of population vulnerability; 3.65\%, between 1.5 and $1.99 ; 6.2 \%$, between 2 and 2.49 ; and $5.5 \%$, between 2.5 and 3 .

If divided by population range, there is no apparent significant correlation of any kind between the population vulnerability and the district population, while there may be a hyperbolic correlation with the district agricultural area. In other words, population vulnerability is lower in the extremes of agricultural area (in hectares) district, while hyperbolic growth in intermediate values.

The vulnerability of species and ecosystems was previously defined as the the sum of the accumulated deforestation rate from 2001 to 2014 and the number of Natural Protected Area (ANP) in the district. Despite having 1,474 districts that did not accumulate any level of deforestation between 2001 and 2014, this should not be a positive indicator, since that most of them did not have forests of any kind in the first place. ${ }^{6}$ In this sense, the districts that had greater vulnerability of species and ecosystems were the districts of Echarate (province of La Convención, department of Cusco), Tambopata (Tambopata, Madre de Dios), Lieutenant Manuel Clavero (Putumayo, Loreto) and Moyobamba (Moyobamba, San Martín), with 4.0133, 3.0079, 3.0038 and 2.2054, respectively. There are 1336 districts that do not have any type of vulnerability of species and ecosystems, as they do not have an ANP neither an accumulated rate of deforestation at all.

The vulnerability of species and ecosystems demonstrates certain interdepartmental disparities. On the one hand, Madre de Dios has an average vulnerability of species and ecosystems of 1.12; Loreto, with one of 0.48 ; Pasco, with one of 0.46 ; Ucayali, with one of 0.35; and San Martín, with one of 0.35. It should be noted that all regions with high levels of such vulnerability are found in the high forest and low jungle of Peru, with the exception of Pasco, which is predominantly found in the highlands. On the other hand, Tacna and Moquegua have a virtual zero vulnerability, while Huancavelica has 0.0004 and twelve other departments do not reach the value of 0.10 . The distribution of districts by their vulnerability of species and ecosystems has a $16.35 \%$ with a least one, while the remaining 6.68\% in between one or more. Also, there is no apparent correlation between the vulnerability of species and ecosystems, with the average district population, nor with the average agricultural area (in hectares).

\footnotetext{
${ }^{5}$ Within the ranges of 1.5 and 1.99 and 2.5 and 3 of population vulnerability, the districts within them necessarily need to have a monetary poverty headcount larger than $50 \%$, while the missing ranges are of comparatively lower monetary poverty.

${ }^{6}$ In terms of accumulated deforestation between 2001 and 2014, Pajarillo (in the province of Mariscal Cáceres, department of San Martín) with $82.22 \%$ and Campoverde (province of Coronel Portillo, department of Ucayali) with $73.94 \%$ should be considered as districts that are remaining as environmentally vulnerable. Additionally, it should be noted that 16 of the 17 districts with the highest rate of accumulated deforestation are in the department of San Martín.
} 
Regarding the environmental functions, services and assets of the Municipalities, it was defined as the lack of an Office or Environmental Unit and of instruments of Disaster Risk Management. Therefore, for each service that is missing, the variable of functions, services and environmental assets takes the value of one, being able to reach up to two in total. For this indicator, disparities are still found, although with less dispersion. For example, while Amazonas has a value of 1.33, Arequipa a 1.23 and Áncash a 1.18, departments like Madre de Dios have a 0.4, Callao a 0.5, and Ucayali a 0.5. The distribution between the natural regions and the departments by environmental functions, services, and average assets does not show a specific concentration.

In terms of the distribution of the number of districts according to their vulnerability of environmental functions, services and assets, $28 \%$ of the districts did not have any lack of functions, services and assets (that is, they provided both), while $51 \%$ had only one of them and $21 \%$ had absence of both. It also appears that the higher the average population, there is an apparent less lack of functions, services and environmental assets. The economic, social, and cultural assets of the municipalities were approximated through the sum of two binary variables: if the agricultural area is greater than the population; and if the municipality carried out activities to encourage tourism. As in the previous variable, the economic, social, and cultural assets do not show a high dispersion among departments but remain close to the average. Madre de Dios, Pasco and Ucayali show the highest values of this indicator (with a 1.30,1.22, and 1.21, respectively). As a contrast, Callao, Cajamarca, and Loreto have figures of 0.67, 0.71, and 0.74, respectively, the lowest assets in Peru. The case of lower assets is again in regions predominantly of the highlands, high forest, and low jungle.

Moreover, $19.7 \%$ of the districts have zero economic, social and cultural assets, while $69.41 \%$ have one of these assets, and $10.89 \%$ have two assets. Additionally, while the average population seems to have no correlation with economic, social and cultural assets, the average district agricultural area apparently has a positive correlation. In other words, the greater the average agricultural area, apparently, the greater the amount of economic, social and cultural assets. However, this might be due to the fact that one of the components of the variable in question is that the district has an agricultural area (in hectares) greater than the population, with which the assets that comply with them will have at least one insured in its total.

In the case of the infrastructure vulnerability of the Municipalities, three questions are being added: whether it received financing for infrastructure and/or social programs in the district, whether it received transfers for social and productive infrastructure projects, and whether they had health infrastructure. While Ucayali is the largest by far with a value of 2.14, while Piura and Madre de Dios are in a second (with a 1.71) and third place (with a 1.70), respectively. On the other hand, Tacna is the only department with an average infrastructure vulnerability below one (0.92), while Lima (1.02) and Moquegua (1.05) also had low values, all from the coast natural region. Moreover, $15.55 \%$ of the districts did not have infrastructure of any kind (within the definition mentioned above), $37.04 \%$ had one in infrastructure, $43.72 \%$ with two and only $3.69 \%$ with three. In addition, the infrastructure vulnerability has an apparent positive correlation with the average district population and with its average agricultural area. In other words, the higher the average population, the greater the infrastructure seems and vice versa, as with 
the average district agricultural area.

The disaggregation by vulnerability by average population is presented in Figure 1, shows the sum of the population, species and ecosystems, environmental functions, services and assets, economic, social and cultural assets, and infrastructure vulnerabilities. Out of this figure, the greater the district population, the lower the absence of functions, services and average environmental assets, and the lower are the economic, social and cultural assets. A hypothesis to be tested is that districts with the largest population may be those that have more relative budgetary resources and may offer a series of services such as environmental and/or tourism promotion. However, there is no apparent correlation between the district population and the average population vulnerability ${ }^{7}$, nor with the vulnerability of species and ecosystems ${ }^{8}$, nor with the average infrastructure, nor with the total average vulnerabilities. ${ }^{9}$

In the case of exposure to natural disaster by district population, the data shows a hyperbolic trend, with lower values at both ends of the population values. In addition, the distribution shows that the districts that have between 5,000 and 10,000 inhabitants have greater exposure to average natural disasters (on average, 5.12). In a similar way, it can be observed that from 10,000 inhabitants per district onward, the exposure to average natural disasters is reduced to great strides. This could be explained by large migratory movements of population towards districts with less exposure to climate changes.

Finally, Madre de Dios is the department with the highest total of vulnerabilities, reaching 6.57. Other departments with large values of this variable were Ucayali with a 5.27, and six departments (Apurímac, Ayacucho, Loreto, Pasco, Piura and Puno) with values between 4.5 and 4.7. On the other hand, the lowest values were the departments of Callao, Tacna, Tumbes, Ica, and Lima with 2.44, 3.14, 3.24, 3.25, and 3.30, respectively. As it happened with some of its components, although the highest values were found primarily in departments of the highlands, low jungle, and high forest (with the exception of Piura), the lowest values were found in coastal departments.

\section{Conclusions and Final Remarks}

One of the main requirements to implement climate change adaptation measures is to ensure that the vulnerability of these risks can be measured to focus on the efforts of the different stakeholders involved. In this sense, a vulnerability index based on a multi criteria analysis was developed in three parts. In the first one, threework axes were chosen following the fifth IPCC report guidelines: climatic phenomena dangers, territorial exposure, and subjects' vulnerability. The territorial area analysis was carried out at the district level to understand population exposure. With regard to subjects, five indicator groups were identified, and measurable variables were chosen:

\footnotetext{
${ }^{7}$ Moreover, it seems to reduce with increasing average population, but it would be needed the exclusion of districts with a population lower than 5,000 to include with larger robustness any apparent correlation.

8 Where apparently there is a hyperbolic relation, with the lowest values of species and ecosystems vulnerability in both extremes of districts population.

9 The argument may be done that the correlation between district population and total average vulnerabilities is negative, but some of its values may apparently question that conclusion.
} 
population; species and ecosystems; functions, services, and environmental municipalities' assets; economic, social and cultural assets; and infrastructure. Next, data was searched for each variable and it was systematized in a multi-criteria database. Finally, an index (0-15) was developed to calculate socio-climatic vulnerability of all the Peruvian District Municipalities distributed by department. They were classified according to social, climatic and socio-climatic vulnerability range to understand how many problems they have to face. As it was mentioned, it is required to do future research that using this same framework could be based on running cross-sectional regressions among the multiple variables found on this variable. With additional resources, the same dataset could be found for all the years where the data sources were found at and potentially run panel data regressions to complement the former ones. Therefore, while it is not possible to find precise and disclosed scenarios for Peru, this facilitates a targeting instrument for public policies that can generate better climate change risk management and contribute to the Sustainable Development Goals commitments fulfillment.

\section{References}

ASOCAM. (2011). Experiencias en adaptación al "Cambio Climático" en Latinoamérica: Avances en políticas públicas nacionales, el accionar local de proyectos y una reflexión sobre su articulación. Quito.

BID, CEPAL. (2014). La Economía del Cambio Climático en el Perú. BID.

Bouroncle, C., Rodríguez, C., \& Florián, M. (2016). Sistema Nacional de Indicadores de Adaptación al Cambio Climático (SLACC): definición del conjunto de indicadores.

Brooks, Nick. (2014). Indicadores para el monitoreo y evaluación de la adaptación. Briefing.

C. Glavovic, B., \& P. Smith, G. (2014). Adapting to Climate Change: Lessons from Natural Hazards Planning. Springer.

Christiansen, L., Schaer, C., Larsen, C., \& Naswa, P. (2016). Monitoring \& Evaluation for climate change adaptation. UNEP DTU.

Climate - eval. (2015). Good Practice Study on Principles for Indicator Development, Selection, and Use in Climate Change Adaptation Monitoring and Evaluation.

GIZ. (2014). Seguimiento y Evaluación de la Adaptación a Niveles Agregados: Un Análisis Comparativo de Diez. Sistemas. Bonn: GIZ.

Gohari, A., Javad, M., \& Eslamian, S. (2015). A Multi-model Frameworkk for Climate Chhange Impact Assessment. En W. Leal, Handbook of Climate Change Adaptation. Hamburg: Springer Reference.

Harari, Y. (2015). Homo Deus, breve historia del mañana. Lima: Penguin Random House.

IPCC. (2001). Climate Change 2001: Impacts adaptation, and vulnerability. Contribution of Working Group II to the Third Assesment Report of the Intergovernmental Panel on Climate Change. Cambridge: Cambridge University Press.

IPCC. (2014). Cambio Climático 2014. Impactos, adaptación y vulnerabilidad. Resumen para responsables de políticas. Grupo Intergubernamental de Expertos sobre el Cambio Climático.

Leal, W. (2015). Handbook of Climate Change Adaptation. Heidelberg: Springer Reference.

Mathew, S., Trück, S., Truong, C., \& Davies, P. (2016). Monitoring and Evaluation in adaptation. Gold Coast: National Climate Change Adaptation Research Facility.

MINAM - CENEPRED. (2013). La adaptación al cambio climático y la gestión del riesgo: reflexiones e mimplicancias. Lima: Proyecto de Inversión Pública y Adaptación al Cambio Climático - GIZ.

MINAM. (2014). Estrategia Nacional ante el Cambio Climático. Lima: Ministerio del Ambiente.

MINAM. (2016). El Perú y el Cambio Climático. Tercera Comunicación Nacional del Perú. Lima: MINAM.

MINAM. (2016). Estrategia Nacional sobre Bosques y Cambio Climático. Lima.

Naciones Unidas. (2008). Preparándose para el futuro. Bogotá: UNODC.

Naciones Unidas. (2015). Convención Marco sobre el Cambio Climático. Parus: FCCC. 
Naciones Unidas. (2019). Perspectivas del Medio Ambiente Mundial GEO 6: Resumen para responsables de formular politicas. Nairobi: Sección de Servicios de publicaciones, ONUN.

Naswa, P., Traerup, S., Bouroncle, C., Medellín, C., Imbach, P., Louman, B., \& Spensley, J. (2015). Buenas prácticas para el diseño e implementación de sistemas nacionales de monitoreo para la adaptación al cambio climático. Copenhagen: Climate Technology Centre \& Network.

Schmidt-Thomé, P., Ha Nguyen, T., Long Pham, T., Jarva, J., \& Nouttimäki, K. (2015). Climate Change Adaptation Measures in Vietnam: Developmen and Implementation. Springer.

Smith, B., Cuccillato, E., \& Anderson, S. (2014). Monitoring and evaluating climate adaptation: a review of GCCA experience. Briefing.

Tirole, J. (2016). La economía del bien comín. Madrid: Presses Universitaires de France, Taurus.

Tirole, J. (2016). La economía del bien común. Madrid: Presses Universitaires de France.

Valverde, A. (2014). Los condicionantes de la fase de diseño de políticas: el caso de la política de adaptación al cambio climático en el Perú. Revista de Ciencia Política y Gobierno, 183-212.

Vardakoulias, O., \& Nicholles, N. (2015). A Socio-Economic Evaluation of Community -based Adaptation: A Case Study in Dakoro, Niger. En W. Leal, Handbook of Climate Change Adaptation. Hamburg: Springer Reference.

\section{Annex}

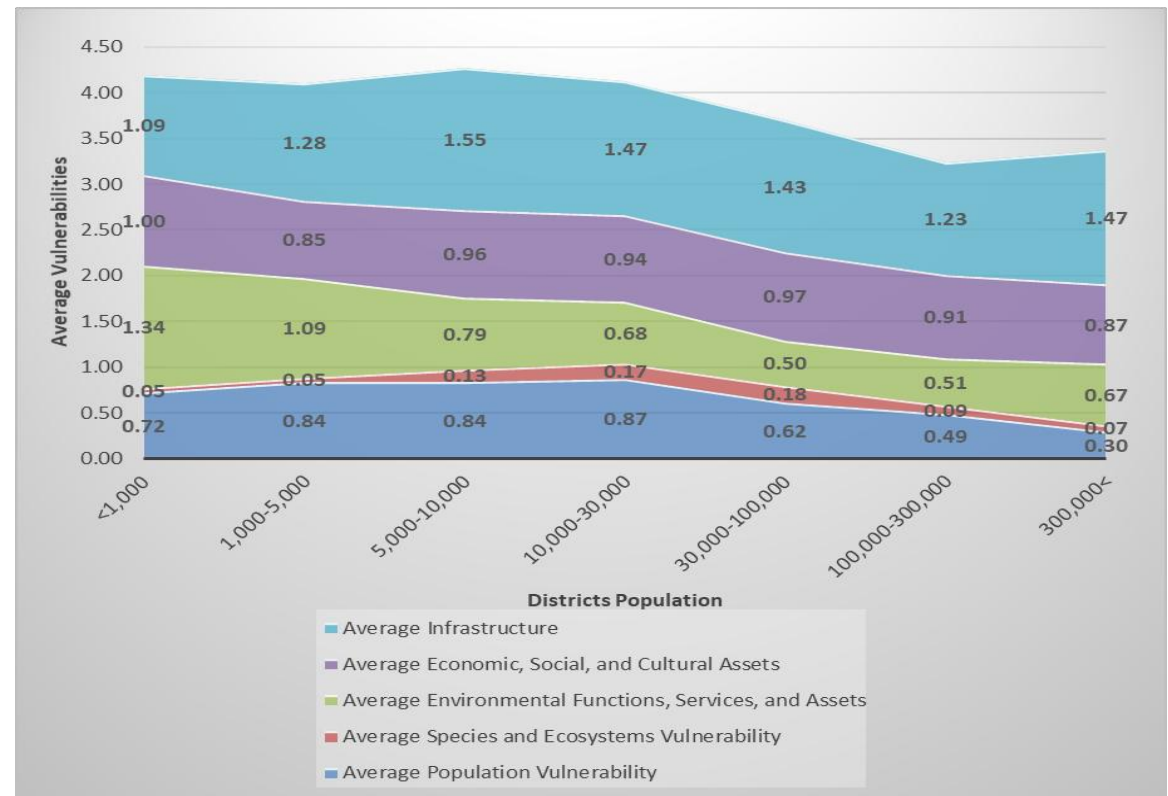

Figure 1. Peru: Average Population Vulnerability; Average Environmental Species and Ecosystems Vulnerability; Average Environmental Functions, Services, and Assets; Average Economic, Social, and Cultural Assets; Average Infrastructure, by District Population, 2017

Source: RENAMU 2018, INEI; MINAM, 2015; Defensoría del Pueblo, 2018 \& INEI, 2015. Elaborated for this paper. Average infrastructure ranges from 0 to 3; average economic, social, and cultural assets from 0 to 2; average environmental functions, services, and assets from 0 to 2; average species and ecosystems vulnerability; from 0 to 5; average population vulnerability from 0 to 3. 
Table 1. Peru: Districts’ Exposure to Natural Disasters, 2017

\begin{tabular}{|l|c|}
\hline Natural Disaster & $\begin{array}{c}\text { Exposed } \\
\text { Districts }\end{array}$ \\
\hline Alluvion & 80 \\
\hline Snowfall & 248 \\
\hline Electric storms & 350 \\
\hline Urban fires & 408 \\
\hline Hill landslides & 430 \\
\hline Floods & 476 \\
\hline Forest fires & 477 \\
\hline Hail & 507 \\
\hline Huaycos & 570 \\
\hline Ground slides & 684 \\
\hline Frost & 739 \\
\hline Strong winds & 801 \\
\hline Droughts & 880 \\
\hline Heavy rains & 1163 \\
\hline
\end{tabular}

Source: RENAMU 2018.

Out of 1736 districts (with data)

Table 2. Peru: Average Total Vulnerabilities by Department, 2017

\begin{tabular}{|c|c|c|c|c|c|c|c|}
\hline Departments & Districts & $\begin{array}{c}\text { Average } \\
\text { Population } \\
\text { Vulnerability }\end{array}$ & $\begin{array}{c}\text { Average Species and } \\
\text { Ecosystems } \\
\text { Vulnerability }\end{array}$ & $\begin{array}{c}\text { Average Environmental } \\
\text { Functions, Services, and } \\
\text { Assets }\end{array}$ & $\begin{array}{c}\text { Average Economic, } \\
\text { Social, and Cultural } \\
\text { Assets }\end{array}$ & $\begin{array}{c}\text { Average } \\
\text { Infrastructure }\end{array}$ & $\begin{array}{c}\text { Average Total } \\
\text { Vulnerability }\end{array}$ \\
\hline Amazonas & 79 & 0.5586 & 0.1554 & 1.3291 & 0.7975 & 1.1899 & 4.0305 \\
\hline Áncash & 156 & 0.5982 & 0.0128 & 1.1795 & 0.8974 & 1.2949 & 3.9828 \\
\hline Apurímac & 76 & 1.1790 & 0.0132 & 1.0658 & 0.7895 & 1.5658 & 4.6132 \\
\hline Arequipa & 102 & 0.7482 & 0.0294 & 1.2353 & 1.0294 & 1.2745 & 4.3168 \\
\hline Ayacucho & 109 & 1.4451 & 0.0226 & 0.8807 & 0.8349 & 1.5046 & 4.6879 \\
\hline Cajamarca & 119 & 0.8994 & 0.0989 & 1.0000 & 0.7059 & 1.3782 & 4.0823 \\
\hline Callao & 6 & 0.1082 & 0.0000 & 0.5000 & 0.6667 & 1.1667 & 2.4415 \\
\hline Cusco & 103 & 0.7926 & 0.0713 & 0.6311 & 1.0097 & 1.5243 & 4.0289 \\
\hline Huancavelica & 91 & 0.5088 & 0.0004 & 0.9451 & 0.8462 & 1.4725 & 3.7729 \\
\hline Huánuco & 73 & 0.6242 & 0.0843 & 0.9041 & 1.0000 & 1.4658 & 4.0785 \\
\hline Ica & 40 & 0.0818 & 0.1500 & 0.6750 & 1.1000 & 1.2500 & 3.2568 \\
\hline Junín & 115 & 1.3823 & 0.1092 & 0.7652 & 0.9565 & 1.1739 & 4.3872 \\
\hline La Libertad & 78 & 0.6489 & 0.0389 & 0.8077 & 0.9872 & 1.2692 & 3.7519 \\
\hline Lambayeque & 36 & 0.3882 & 0.0556 & 0.6667 & 0.8333 & 1.5000 & 3.4437 \\
\hline Lima & 160 & 0.3411 & 0.0688 & 0.9875 & 0.8875 & 1.0188 & 3.3036 \\
\hline Loreto & 50 & 1.1006 & 0.4807 & 0.8200 & 0.7400 & 1.4000 & 4.5414 \\
\hline Madre de Dios & 10 & 2.0464 & 1.1243 & 0.4000 & 1.3000 & 1.7000 & 6.5707 \\
\hline Moquegua & 19 & 0.8311 & 0.0000 & 0.9474 & 1.1579 & 1.0526 & 3.9890 \\
\hline Pasco & 27 & 0.9161 & 0.4615 & 0.6667 & 1.2222 & 1.4074 & 4.6739 \\
\hline Piura & 61 & 1.0994 & 0.0541 & 0.6393 & 1.0164 & 1.7049 & 4.5142 \\
\hline Puno & 102 & 1.2783 & 0.0402 & 0.9510 & 0.8333 & 1.5294 & 4.6322 \\
\hline San Martín & 72 & 0.4603 & 0.3452 & 0.8611 & 0.9722 & 1.4028 & 4.0417 \\
\hline Tacna & 25 & 0.2818 & 0.0000 & 0.9600 & 1.0800 & 0.9200 & 3.2418 \\
\hline Tumbes & 13 & 0.1429 & 0.3077 & 0.5385 & 1.0000 & 1.1538 & 3.1429 \\
\hline Ucayali & 14 & 1.0641 & 0.3520 & 0.5000 & 1.2143 & 2.1429 & 5.2732 \\
\hline Note: & & & & & & & \\
\hline
\end{tabular}

Note: Average infrastructure ranges from 0 to 3; average economic, social, and cultural assets from 0 to 2; average environmental functions, services, and assets from 0 to 2; average species and ecosystems vulnerability; from 0 to 5 ; average population vulnerability from 0 to 3 .

Source: RENAMU 2018, INEI; MINAM, 2015; Defensoría del Pueblo, 2018; CENAGRO 2012, MINAGRI; INEI, 2015. 